\title{
The academic writing process in Spanish universities: perceptions of students and faculty / El proceso de escritura académica en la universidad española: percepciones de estudiantes y profesores
}

\author{
Javier Marín ${ }^{\mathrm{a}}$, Sonia López ${ }^{\mathrm{b}}$, and Julio Roca-De-Larios ${ }^{\mathrm{a}}$ \\ ${ }^{a}$ Universidad de Murcia; ${ }^{b}$ Universidad Pompeu Fabra
}

\begin{abstract}
This paper is intended as an exploration of university faculty and students' perceptions of a number of dimensions involved in the written composition of academic texts. We analysed the responses to scale 3 in the European Writing Survey (EUWRIT) (in its Spanish version: Encuesta Europea sobre la Escritura Académica, EEEA) by a group of social science and humanities students $(n=1,030)$ and faculty $(n=230)$ from nine Spanish universities. We then examined the similarities and differences in their perceptions and established a factorial structure of the different dimensions underlying the writing process. The data indicate that both groups concur in the value assigned to both changing ideas in the course of the composition process (although this process seems to be understood differently by each group) and the revision and feedback processes. The students, however, claim to be involved in more planning and previous reading activities than the teachers perceive them to be. The significance of these results for a processoriented perspective in academic writing is discussed.
\end{abstract}

Keywords: composition processes; academic writing; faculty; students; higher education

Resumen: En este artículo se analizan las percepciones de los estudiantes universitarios y sus profesores sobre varias dimensiones del proceso de composición de textos académicos. Para ello examinamos las respuestas a la escala 3 del cuestionario Encuesta Europea sobre la Escritura Académica (EEEA) por parte de una muestra de estudiantes $(n=1,030)$ y profesores $(n=230)$ en los grados de ciencias sociales y humanidades de nueve universidades españolas. Se estudian las diferencias y similitudes en la percepción del proceso de escritura entre ambos grupos y se establece la estructura factorial de las diferentes dimensiones que subyacen a la percepción del proceso escritor. Los resultados indican que las percepciones de ambos colectivos coinciden en 
el valor atribuido a la modificación de las ideas a lo largo de la composición (aunque este proceso parece entenderse de forma diferente por cada grupo) y a los procesos de revisión y de feedback. Sin embargo, los estudiantes manifiestan realizar actividades de planificación y lectura previa con más frecuencia de la que parecen percibir los profesores. En la última parte del estudio se discute el significado de estos resultados para la interpretación de la dimensión procesual de la escritura académica.

Palabras clave: procesos de composición; escritura académica; profesores; estudiantes; enseñanza superior

Academic writing is regarded as a complex activity which involves students' mastery of a wide range of competences. These competences include the effective management of the discursive elements involved in producing texts, knowledge of the disciplines and genres associated with them, understanding of the new forms of literacy, correct and appropriate use of the language, consideration of the expectations and demands of the discourse communities within which the text falls and is interpreted, and handling and coordinating the regulation processes inherent to the act of writing (e.g., Hyland, 2011; Kruse, 2013).

Of all of these competences, the one related to the process of regulating the composition is regarded as essential in academia due to the importance that tends to be attached to these processes for the quality of the text produced. In fact, this relationship has been explored from a variety of theoretical and methodological approaches which encompass everything from cognitive and socio-cognitive to more socio-cultural perspectives. According to Castelló, Bañales Faz, and Vega López (2010), these approaches differ from each other theoretically in the value they assign to the metacognitive, motivational and contextual factors involved in generating texts, and methodologically in the data-gathering and analysis procedures used while writing either individually or collaboratively.

From a cognitive perspective, based on the pioneering model proposed by Flower and Hayes (1980), the most recent process-writing proposals (e.g., Alamargot \& Chanquoy, 2001; Roussey \& Piolat, 2005) state that in addition to being viewed as a communicative practice, the composition of texts should be viewed as a complex problem that writers have to resolve by activating top-down regulation processes (planning), as well as bottom-up processes (revision). While the former entail establishing different kinds of objectives and sub-objectives (regarding content, rhetoric, etc.) which allow the writer to control and coordinate the text production in a more or less integrated way (Carey, Flower, Hayes, Schriver, \& Haas, 1989; Torrance \& Galbraith, 2006), the revision processes allow them to control their attainment of the previously-established objectives through activities that involve detecting, diagnosing and solving both local and global problems (Hayes, Flower, Schriver, Stratman, \& Carey, 1987; Midgette, Haria, \& MacArthur, 2008). Both kinds of processes are not linear in nature but more recursive, and their efficacy regarding the text produced depends on the writers' competence in managing them. 
However, cognitive contributions are limited when the goal is to explain the regulation processes according to variables such as the motivation to write or the context in which the writers compose their texts. This has been borne out by a series of studies (e.g., Graham \& Harris, 2000; Zimmerman \& Kitsantas, 2007) whose common denominator is the fact that they consider writing a sociocognitive activity in which the regulation skills are acquired sequentially and at different levels (cognitive, behavioural, affective, etc.), shifting from being socially controlled and motivated (through processes of observation and emulation) to ultimately being self-controlled and self-motivated (through selfregulation processes) (see Castelló et al., 2010). Nonetheless, one of the limitations of the studies conducted from this theoretical perspective is that their results and conclusions, which are primarily based on the analysis of writing tasks performed in primary and secondary educational settings, cannot be confidently extrapolated to other settings characterized by more complex tasks, such as university. Likewise, this is a vein of research which, just like the aforementioned cognitive perspective, has been limited to analysing individual composition processes while ignoring the co-regulation processes that appear when text composition is viewed as a dialogic, situated activity performed by the members of a discourse community within a given cultural context. These processes tend to be analysed from the sociocultural perspective.

From this vantage point, it is postulated that co-regulation is the mechanism that allows the learner to appropriate the skills and other cultural tools provided them by interaction either with the instructor and other more advanced students (inter-psychological plane), or with other voices and tools that have already been internalized (intra-psychological plane) (Castelló, 2007; Flower, 1994) and use them independently to construct texts (Englert, Mariage, \& Dunsmore, 2006). Based on these premises, a significant number of studies have aimed to show how co-regulation takes place among university students in the collaborative planning and revision processes, and to clarify how apparently individual regulation processes carried out by expert writers when doing authentic tasks (e.g., writing scholarly articles) are truly mediated by the prevailing criteria in the discursive communities within which the activity fits (see Castelló et al., 2010).

Regardless of whether it is envisioned as an individual cognitive practice or as a social and institutional practice, and whether it is analysed from cognitive, socio-cognitive or sociocultural perspectives, one of the basic competences required when producing academic texts is for students to at the very least be familiar with the recursive nature of the composition process and to acquire a certain skill level in handling and coordinating the activities involved in the subprocesses of planning, formulating and revising, as well as in effectively choosing, interpreting and using the sources (Kruse, 2013).

Based on this, and given the small number of far-reaching studies on academic writing practices and processes at Spanish universities (see the first article in this special issue), the goal of this study is to ascertain faculty and student perceptions of the processes involved in writing academic texts in general. We would like to underscore the 'general' nature of our analysis because, according to the scale of 
the survey used (see below), our goal is not to explore the diversity of composition processes that might be expected when dealing with specific text genres. This 'diversity' of processes would exist because the discursive conventions of each genre should be viewed not only as the ways in which different kinds of knowledge are harnessed but also, and perhaps more importantly, as instruments which allow knowledge to be constructed and relationships with the activities in which it develops to be forged (Camps \& Castelló, 2013).

Accordingly, the goals of this study are:

(1) To identify the perceptions of students and faculty at different Spanish universities of the processes involved in academic text composition.

(2) To assess to what extent and in what specific processes these perceptions are shared by both groups.

\section{Method}

The design of the study is descriptive and latitudinal, and it utilized a quantitative methodology.

\section{Participants}

Even though the project described in the first article of this special issue includes a sample of 280 faculty members and 1,044 students from different disciplines at the Bachelor's and post-graduate levels of nine Spanish universities, in this study we focused on analysing the responses of a sub-sample of students $(n=733)$ and faculty members $(n=230)$ in the social and legal sciences and arts and humanities degree programmes.

The reasons for choosing this sub-sample are outlined below. In the total sample of students, in line with the proportions of the university student population in 2012 (Ministerio de Educación Cultura y Deporte (MECD), 2012), we found that $90 \%$ were engaged in Bachelor's degrees, $7.8 \%$ in Master's degrees and $2.3 \%$ in doctoral programmes. In a preliminary examination of the data gathered, we noticed that the activities related to academic writing varied considerably depending on the academic level. Before statistically analysing the data, we checked that they fulfilled the criterion of homogeneity through the Levene Test and found satisfactory results in all cases (all values $F(2,1159)<1.93$, $p>.14$ ). We then applied a multivariate analysis of variance (MANOVA), with the factor being the kind of degree programme (Bachelor's, Master's or doctorate) and the dependent variable $(D V)$ being the responses to items $2 \mathrm{~A}, 2 \mathrm{~B}, 2 \mathrm{C}, 2 \mathrm{D}$ and 2E (Kruse, 2013). The results showed the existence of significant differences among the three levels involved in the study $(F(10,2310)=2,774, p=.002)$. The differences were primarily due to the fact that the mean number of hours per week spent writing in Bachelor's programmes $(\bar{x}=3.23)$ was lower $(p<.01)$ than in Master's $(\bar{x}=3.51)$ and doctoral programmes $(\bar{x}=3.81)$, while the difference between the latter two was not significant. 
This difference in the number of hours spent writing can lead to substantial changes in the nature and distribution of the processes in which we are interested. However, in order to avoid the descriptive heterogeneity that this would lead to, we decided to restrict our analysis to the 1,030 Bachelor's degree students who responded to the survey, who had a valid response rate equal to or higher than $60 \%$ (14 participants were eliminated because they did not fulfil this criterion). The Master's and doctoral students $(n=118)$ were excluded from the analysis. Therefore, the results of our study are circumscribed to the first stage in university education in Spain, a stage in which relatively little time tends to be spent writing academic texts.

Once the sub-sample of Bachelor's degree students was chosen, we performed another ANOVA on the variables that codified the assignment of tasks (item 2: A-E, see Kruse, 2013) to check whether there were differences in these variables associated with the chosen students' different fields of study. The results showed that there were significant differences overall between the different fields (Wilks $\lambda=.874, F(15,2860)=9.509, p<.001)$. The post-hoc comparisons indicated the existence of two groups among them: first was the social and legal sciences, which was grouped with the arts and humanities, and the second was the health sciences, which was grouped with engineering and architecture. No significant differences were found among the components of each group $(p>.37)$, but differences were found among the components of different groups $(p<.001)$ because writing activities are systematically more common in the social and legal sciences and arts and humanities than in the health sciences, engineering and architecture. For this reason, in order to devise the final sample of students to analyse, we chose the 733 students in the social and legal sciences $(n=703)$ and arts and humanities $(n=30)$, who as a whole accounted for $70.21 \%$ of the total participants in Bachelor's degree programmes.

Regarding the faculty sample, we chose the 230 professors (41 from arts and humanities and 189 from social and legal sciences; that is, $82.4 \%$ of the total faculty) who came from the same fields as the students.

\section{Materials}

In order to fulfil the prime goal of this study, we used scale 3 ('The composition process') in the European Writing Survey (EUWRIT) (in its Spanish version: Encuesta Europea sobre la Escritura Académica, EEEA) (Chitez, Kruse, \& Castelló, 2015; Kruse, 2013; Kruse \& Chitez, 2012), whose characteristics were discussed in the first article of this special issue. Just like the entire survey, the scale we used has two versions, and each of them seeks to capture the perceptions of either the students or the faculty on the same aspects of writing.

Even though the original survey administered to our student sample had a total of 12 items within this scale, we restricted our analysis to the first six items since these items are directly related to the behaviours associated with the process of writing. These items describe aspects related to the different sub-processes of composition, as established in the classic cognitive models (e.g., Flower \& Hayes, 
1980): planning (items 1-3), formulation (item 4) and revision (items 5-6). The discarded items (from 7 to 12) referred to students' assessments of the different components outside the composition process, including instructors, university and attitude towards plagiarism. In turn, the survey administered to the faculty followed the same patterns as the student survey, with the unique feature that the responses to the items were based on their inferences of students' behaviour based on 'their own experience' as instructors. This is a problematic feature of the data, as we shall discuss below, since it is impossible to ensure that the instructors' assessments are the result of direct knowledge of the different phases students go through when writing a text instead of simply their evaluation based on texts that have already been produced. Therefore, we should interpret the results from the faculty sample as phenomena related to their opinion more than as a direct assessment of observed deeds through contact with students and their writing efforts.

\section{Data analysis}

The data from the surveys were analysed according to the differences between students and faculty on the one hand, and the correlation patterns among the items in each group on the other. Comparing the assessments of students and faculty not only provides information on the descriptive components of the two main actors in the academic writing process but can also help us to grasp some phenomena that occur in the academic and educational setting at Spanish universities today. To this end, we examined the student/faculty differences in each of the items analysed in order to clarify the unique features of each sample and, in a complementary fashion, we also provide the results of a discriminant analysis which allowed us to pinpoint the most important differences when describing each group. Likewise, we performed a correlation analysis to analyse the possible association among items in each sample and to understand faculty and students' global conceptions of the composition process. This association is qualified by a factorial analysis which enabled us to determine the latent variables underlying the responses of both groups.

\section{Results}

\section{Analysis of the differences between students and faculty}

Table 1 shows the means and standard deviations of the student and faculty estimates on each of the items, along with the level of significance of the differences.

An initial examination of these data indicate that both faculty and students show a mean assessment which is located very close to the midpoint of the scale, but that tend to be slightly higher. The lowest figure corresponds to faculty's assessment of students' planning of texts $(\bar{x}=2.69 ; S D=1.07)$, while the highest one is the students own scores on reading the documents before undertaking the writing process $(\bar{x}=3.97 ; S D=0.94)$. Therefore, there are no assessments on the 
Table 1. Means (standard deviations) of student and faculty assessments of the different processes involved in writing. Values of the test of significance of the differences and value of the effect size $\left(\eta^{2}\right)$.

\begin{tabular}{|c|c|c|c|c|c|}
\hline Item & Faculty & Student & $F(1,957)$ & $p$ & $\eta 2$ \\
\hline 1.... planning before writing a text. & $2.69(1.07)$ & $3.76(0.94)$ & 209.37 & .000 & .180 \\
\hline $\begin{array}{l}2 \ldots \text { beginning to write spontaneously } \\
\text { and being carried along by the text } \\
\text { itself. }\end{array}$ & $3.26(1.09)$ & $2.95(1.11)$ & 14.18 & .000 & .015 \\
\hline $\begin{array}{l}3 . . . \text { doing all the readings before } \\
\text { beginning to write. }\end{array}$ & $2.76(1.08)$ & $3.97(0.92)$ & 277.16 & .000 & .225 \\
\hline $\begin{array}{l}\text { 4.... letting their ideas change }[\ldots] \text { as } \\
\text { they write their texts }\end{array}$ & $3.54(0.98)$ & $3.68(0.93)$ & 3.75 & .053 & .004 \\
\hline $\begin{array}{l}5 . . . \text { revision is an essential part of } \\
\text { students' writing. }\end{array}$ & $3.61(1.40)$ & $3.6(0.97)$ & 0.02 & .895 & .000 \\
\hline $\begin{array}{l}6 . . . \text { discussing their texts with someone } \\
\text { and receiving feedback in order to } \\
\text { improve them. }\end{array}$ & $2.81(1.11)$ & $2.7(1.18)$ & 1.56 & .212 & .002 \\
\hline
\end{tabular}

extreme negative end of the sale, yet nor do the positive ratings attain extremely high values.

An analysis of the differences between students and faculty indicates that the former assign significantly higher scores to items 1 ' $\ldots$ planning before writing a text' and 3 '... doing all the readings before beginning to write', while the faculty assign higher mean scores to students on item 2 '... beginning to write spontaneously and being carried along by the text itself'. However, in all cases, the size effect observed is rather moderate. On the other hand, no significant differences can be seen in items 4,5 and 6 .

Based on all of this, we can infer that there is some similarity in student and faculty assessments of the writing process and that these assessments tend to hover around the midpoint of the scale (3: 'I'm not sure'), with the only exception being the assessment of item 3 by students, which almost reaches point 4 ('I agree').

\section{Discriminant analysis}

Using the technique of discriminant analysis, a statistical procedure which allows a set of elements to be classified into two or more categories based on the features that characterize them (Stevens, 2009), we chose those items whose standardized coefficient showed an absolute value higher than 0.5 (see Table 2). As a result, we identified just two items, number 3 'doing all the readings before beginning to write' and number 1 'planning before writing a text' based on which we could correctly discriminate $83.6 \%$ of the students' and faculty assessments following the 'let-one-out' procedure.

On the other hand, the figures indicate that there is agreement between students and faculty regarding the fact that the former (a) let their ideas be carried 
Table 2. Standardized coefficients of canonical discriminant functions.

Item

Function 1

1.... planning before writing a text.

$2 \ldots$ beginning to write spontaneously and being carried along by the text itself.

3.... doing all the readings before beginning to write.

$4 . .$. letting their ideas change [...] as they write their texts $\quad .127$

$5 . .$. revision is an essential part of students' writing. -.335

6 .... discussing their texts with someone and receiving feedback in order to $\quad-.232$ improve them.

along by the text itself, (b) discuss their texts with someone and receive feedback in order to improve them and (c) believe that revision is an essential part of writing.

\section{Correlation analysis}

The Pearson's correlation analysis among the items in the student group resulted in a high number of significant correlations among the six items in the survey (see Table 3), which indicates that the different behaviours that they reflect are part of an integral structure of actions which lead to the production of a text. The pattern of correlations seems to be organized by belonging to (1) the group of items we

Table 3. Correlations between writing processes in the student and faculty samples.

\begin{tabular}{|c|c|c|c|c|c|}
\hline & 1 & 2 & 3 & 4 & 5 \\
\hline Item & Students & & & & \\
\hline 2 & $-.211 * *$ & & & & \\
\hline 3 & .095 & $-.214 * *$ & & & \\
\hline 4 & -.118 & $-.164 *$ & $.250 * *$ & & \\
\hline 5 & $.144^{*}$ & $-.339 * *$ & $.370 * *$ & $.278 * *$ & \\
\hline 6 & $.243 * *$ & $-.195 * *$ & $.350 * *$ & $.169 *$ & $.439 * *$ \\
\hline & Faculty & & & & \\
\hline 2 & $-.529 * *$ & & & & \\
\hline 3 & $.313^{* *}$ & $-.193 * *$ & & & \\
\hline 4 & .008 & $.146^{* *}$ & -.068 & & \\
\hline 5 & $.351 * *$ & $-.123 * *$ & $.273 * *$ & .039 & \\
\hline 6 & $.175^{* *}$ & -.028 & $.154 * *$ & .044 & $.278^{* *}$ \\
\hline
\end{tabular}

Note: ${ }^{*} p<.001 ; * p<.05$.

Items

1 .... planning before writing a text.

2 .... beginning to write spontaneously and being carried along by the text itself.

$3 . .$. doing all the readings before beginning to write.

$4 . .$. letting their ideas change [...] as they write their texts

$5 . .$. revision is an essential part of students' writing.

6 .... discussing their texts with someone and receiving feedback in order to improve them. 
could call more 'standardized' or top-down, since they refer to 'more canonical' behaviours according to the classic composition models (e.g., Flower \& Hayes, 1980); or (2) the 'less canonical' or more bottom-up behaviours, which refer to more 'emergent' or 'constitutivist' behaviours (e.g., Galbraith, 1999). The more canonical items include number 1 ' $\ldots$ planning before writing a text', number 3 '.. doing all the readings before beginning to write', number 5 ' $\ldots$ revision is an essential part of students' writing' and number 6 ' $\ldots$ discussing their texts with someone and receiving feedback in order to improve them'. In turn, the items that involve bottom-up procedures include number 2 '.. beginning to write spontaneously and being carried along by the text itself' and number 4 '. . . letting their ideas change $[\ldots]$ as they write their texts'.

The existence of these two groups is validated by the fact that the items in each tend to positively correlate with each other and negatively correlate with the opposite group. Thus, the item on planning (item 1) is positively correlated with the items on text revision (items 5 and 6) and a previous survey of the literature (item 3); while there are also positive correlations among the items that express strategies or actions which are less canonical: beginning to write spontaneously and letting themselves be carried along by the text (items 2 and 4). Regarding the negative correlations, the highest in absolute value occurs between items 1 and 2, but it is trivial since they are conceptually opposite behaviours. Finally, item 4 ('letting their ideas change [...] as they write their texts') which, as mentioned above, is significantly correlated to item 2 within its group, has no significant correlations with the remaining items in the 'canonical' group.

Regarding the faculty responses, we can see a correlation pattern similar to the students', albeit with a few differences (see Table 3). The correlations among the items in the 'canonical' group are all positive, higher than zero and statistically significant, with the sole exception of the coefficient between items 1 and 3, perhaps because this latter item ('doing all the readings before beginning to write') implies a different skill set to faculty than to students. However, surprisingly, the pattern of positive correlations observed among the students for the 'less canonical' group of items is not replicated in the faculty group. In the latter, there is a significant but negative correlation between items 2 ("beginning to write spontaneously and being carried along by the text itself') and 4 ('letting their ideas change $[\ldots]$ as they write their texts'), although it is rather low $(r=-.164)$. Perhaps, similar to item 3, this anomaly is due to the fact that the faculty interpret item 4 differently than the students.

\section{Factorial analysis}

The responses to the six items were subjected to a principal components factorial analysis with the goal finding the dimensions that can organize and summarize the responses of students and faculty. It is important to note that the goal of this analysis is to summarize the direct patterns of data variation and thus yield a simplified comparison (Landau \& Everitt, 2004; Stevens, 2009). This objective should not be confused with that of an exploratory factorial analysis, which seeks 
Table 4. Principal components factorial analysis on the assessment of writing processes by students.

Factor

Item

I External

II Internal

III Ability

information organization

to change

1.... planning before writing a text.

2 .... beginning to write spontaneously and being carried along by the text itself.

3.... doing all the readings before beginning to write.

4.... letting their ideas change [...] as they write their texts

5 .... revision is an essential part of students' writing.

6.... discussing their texts with someone and receiving feedback in order to improve them.

$\begin{array}{lrr}.301 & .819 & .096\end{array}$

$\begin{array}{lll}.052 & -.871 & .135\end{array}$

$\begin{array}{lll}.519 & .338 & -.220\end{array}$

.024

$-.038$

.974

.717

.235

.100

.782

to identify the latent variables that may underlie the data. The results of the analysis on student responses revealed a total of three factors which explain $69 \%$ of the total variance in the scores of this group.

Table 4 shows the components rotated using the VARIMAX method for the student sample. The three resulting factors are: 'use of external information' (F I), 'internal organization of the process' (F II) and 'ability to change' (F III). Factor I encompasses items 3, 5 and 6, which refer to the use of external information sources to include in the writing. Both readings and revision processes (where the text is adapted to the reader) and the use of feedback refer to an external agent other than the writer themselves as the determinant and referent for the contents and structure of the text.

Factor II, 'internal organization of the process', encompasses items 1 and 2. The first refers explicitly to planning and its association with item 2, which refers negatively to spontaneity at the start of the composition process and indeterminateness in the formulation process. The composition of this factor suggests the existence of a planning/improvization dimension. Students who score high on this factor tend to highly value planning and reject the idea of being carried along by the text. Finally, Factor III, which we have called 'ability to change', is made up of a single item: 'letting their ideas change [...] as they write their texts'. Students seems to believe that there is a dimension independent of the previous ones that codifies the tendency to let themselves be influenced by the dynamic of text development and thus totally or partially abandoning their original ideas.

Table 5 shows the result of the principal components factorial analysis on the faculty perceptions of their students' writing process (components rotated using the VARIMAX method). This analysis once again reveals three factors which explain $70.2 \%$ of the total variance in the scores of this group. However, the structure of the factors obtained differs from what we observed for the student sample. 
Table 5. Principal components factorial analysis on the assessment of writing processes by faculty.

Factor

\begin{tabular}{ccc}
\hline I External & I Internal & I \\
information & information & Spontaneity
\end{tabular}

\begin{tabular}{|c|c|c|c|}
\hline 1.... planning before writing a text. & .26 & -.741 & .356 \\
\hline $\begin{array}{l}2 \ldots \text { beginning to write spontaneously and } \\
\text { being carried along by the text itself. }\end{array}$ & -.103 & .037 & -.936 \\
\hline $\begin{array}{l}3 \ldots \text { doing all the readings before beginning to } \\
\text { write. }\end{array}$ & .719 & .158 & .083 \\
\hline $\begin{array}{l}4 \ldots . . \text { letting their ideas change }[\ldots] \text { as they write } \\
\text { their texts }\end{array}$ & .335 & .714 & .276 \\
\hline $\begin{array}{l}5 . . . \text { revision is an essential part of students' } \\
\text { writing. }\end{array}$ & .677 & .113 & .367 \\
\hline $\begin{array}{l}6 \ldots \text { discussing their texts with someone and } \\
\text { receiving feedback in order to improve them. }\end{array}$ & .825 & -.221 & -.007 \\
\hline
\end{tabular}

We have called the first factor 'use of external information' and it encompasses items 3, 5 and 6. Just as in our examination of the students' assessments, the main load of this factor codifies the use and inclusion of information coming from agents other than the writers themselves during the text composition process.

The second factor, which we shall call by the same name as its counterpart in the factorial study on students, 'internal organization', encompasses item 4 ('letting their ideas change [...]'), which has a positive load, and item 2 ('planning'), which has a negative load. The positive load of the item, which indicates spontaneity when composing the text, in combination with the negative load of planning, probably indicates the faculty's belief that students who let themselves be driven by spontaneity and circumstances at the time they start writing do not tend to be systematic writers who use forethought. On the other hand, this factor has a similar structure to what was found in the student sample, although the sign of the factorial loads is opposite. In this case, the students who score high in this factor tend to make few plans prior to writing, and they probably let themselves be carried along by the dynamic of text creation. Finally, the analysis shows the existence of a third factor which is made up solely of item 2, ' $\ldots$ beginning to write spontaneously and being carried along by the text itself'. We have called this factor 'spontaneity', and it can be interpreted as the faculty's belief that there is a dimension that indicates a certain spontaneous attitude among some students as they begin and develop the academic writing process.

\section{Discussion}

This study is a preliminary analysis of student and faculty perceptions of the processes involved in writing academic texts at Spanish universities. The descriptive and relational exploration of the data allowed us to examine the multiplicity 
of dimensions and connections that seem to be present in the formulation of these perceptions.

First, the comparison of means and discriminant analysis has shown that faculty and students primarily differ in two considerations regarding the nature of the activities associated with writing: (1) the planning prior to writing a text; and (2) the previous reading of the references needed before starting the composition process. The students claim to engage in these processes more frequently than their instructors seem to perceive them to do.

The truly salient part of these differences refers to the activities done prior to the act of writing itself (planning and reading of text), not so much to the writing process itself or to the end product of this process. As mentioned above, if the faculty likely construct their perceptions of the nature of students' composition processes based on the texts turned in to them, the differences we are uncovering might then indicate disparities between the students' reports, which are clearly subjective yet based on direct contact with the reality being evaluated, and a more speculative conception, which is what the faculty generate based on their inferences. Based on this interpretation, we should assume that generally speaking the faculty are not totally satisfied with the end product which students submit to them, and they infer that the cause must be a shortcoming in the students' processes of prior reading and planning, as these processes are essential in order to effectively write texts according to certain models that stress the role of knowledge and organization of the content as well as intertextuality (see, for example, Deane et al., 2008; Flower, 1994). On the other hand, we could also speculate that the difference between students and faculty might stem not so much from a different degree of proximity to the students' composition process but to their different evaluations of the final quality of the texts produced. It is possible for students to believe that their writings are higher quality than how the faculty view them, and therefore they differ in their assessment of some of the processes which give rise to the composition of these texts. Unfortunately, the survey has no item which yields a direct assessment of the quality of the texts produced.

Likewise, both groups' shared perceptions on changing ideas throughout the composition process and the role played by revision and feedback when producing texts can be interpreted as a reflection of the fact that these processes are generally considered inherent and essential to the act of writing, albeit with differing degrees of intensity (see Fayol, Alamargot, \& Berninger, 2012). Galbraith (1999, 2009), for example, has suggested that even though the research stemming from classic composition models (e.g., Bereiter \& Scardamalia, 1987; Flower \& Hayes, 1980) view writing as a top-down process in which the previously planned content is captured on the page by words, the act of writing should actually be viewed as a process of 'constituting knowledge' in which the creation of content is partly determined by top-down processes, as well as by episodes of language processing (bottom-up). From this perspective, both the structure and meaning of the sentences are developed as they are produced, and later they are reshaped by revision processes (Hayes, 2012). The faculty and students seem to concur in their perceptions of these features of writing, and this could help us to understand the reason why the former, 
despite their unfavourable opinion of the latter's planning activities, do not question their revision activity. They may believe that revision processes are more inherent than planning processes and therefore less optional in the act of writing.

However, despite the concurrence between the two groups shown in the previous data, the analysis of correlations indicates that their responses to item 4 ('letting their ideas change [...] as they write their texts') are not equivalent. Even though this item correlates negatively with the items in the 'canonical' group (planning, doing previous readings, revising the texts and receiving feedback) in both students and faculty, their correlation with item 2 ('beginning to write spontaneously') within the 'non-canonical' group is positive for students but negative for faculty. This difference must be yet further proof of the two groups' different interpretation of the composition process of academic texts. We might posit that if the faculty tend to view this process as an activity that implies the constant reformulation of ideas aimed at 'transforming knowledge', which is thus incompatible with a spontaneous, immediate form of writing, the students might view the task solely as fulfilling a set of requirements given by a professor and letting themselves by carried along by the dynamism inherent to the act of writing until they exhaust their repertoire of ideas on the topic using a procedure only aimed at 'showing knowledge' (Bereiter \& Scardamalia, 1987).

Finally, the factorial structure of the items is different among students and faculty. Even though there is a shared factor we have called 'use of external information', which encompasses three of the six items in the sub-survey, the remaining items are grouped differently in each sample. While there is a group of spontaneity and planning among the students, with ability to change considered separate, among the faculty spontaneity is the factor which operates separately, leading to a grouping between ability to change and planning.

Even though it is not simple to offer an interpretation of this difference, we may assume that among students the association between planning and spontaneity is based on the beginning of textual formulation: planning would delay their starting to write. Among the faculty, to the contrary, the association between planning and changing ideas as the composition moves forward would not have this time dimension but would instead be more strategic. To the faculty, if the students let themselves be carried away by the features of text composition it is because they lack a representation of the content of the text in the guise of precise, well-organized prior ideas which have not been formulated in the (non-existent) planning phase. Therefore, the students that go through a planning process would be less likely to let the development of the text change their ideas. Spontaneity is a feature which in theory has no obvious association with this strategic component and is thus an independent factor.

\section{Conclusions}

This study shows that the responses of faculty and students are very close to or above 3 , which indicates that both groups generally give reasonably positive assessments of the processes of academic writing at the university. Having said 
this, however, we should note that the pattern of assessment is quite complex, since both groups only partly share perceptions.

Even though the faculty and student assessments are similar in terms of changing ideas through the composition process (although this process seems to be viewed differently by faculty and students) and the value assigned to the revision and feedback processes, they clearly differ in their assessments of reading the materials needed to carry out the writing assignment and the planning processes prior to writing the text.

These differences seem to yet again confirm the reproductive more than epistemic nature of composition processes at Spanish universities, and it would dovetail with the results of other studies in this special issue which document the fact that writing in this context tends to be used more as a mere record of pre-established knowledge than as a tool that fosters the process of developing new knowledge and communicating this knowledge (see Corcelles, Oliva, Castelló, \& Milian, 2015).

In this sense, from the pedagogical standpoint, we should help students to optimize the reading processes inherent in using a variety of texts and materials while developing their abilities to choose, organize and integrate information. On the other hand, the transition towards a more epistemic conception of the planning processes would mean instructing them in procedures aimed not just at generating ideas but also at shaping them in line with the rhetorical objectives to be met depending on the readers' expectations. 


\section{El proceso de escritura académica en la universidad española: percepciones de estudiantes $y$ profesores}

La escritura académica se considera una actividad compleja cuyo desempeño implica el dominio de una amplia variedad de competencias por parte de los estudiantes. Estas competencias comprenden, entre otras, la gestión eficaz de los mecanismos discursivos implicados en la producción del texto, el conocimiento de las disciplinas y de los géneros asociados a las mismas, la comprensión de los nuevas formas de literacidad, el uso correcto y apropiado de la lengua, la consideración de las expectativas y demandas de las comunidades de discurso en las que el texto se inserta e interpreta, y el manejo y coordinación de los procesos de regulación propios del acto de escribir (e.g., Hyland, 2011; Kruse, 2013).

De entre todas estas competencias, la relativa a los procesos de regulación de la composición se considera primordial en el ámbito académico debido a la relevancia que se suele asignar a dichos procesos en la calidad de los textos producidos. De hecho, dicha relación ha sido explorada desde distintos enfoques teóricos y metodológicos que comprenden tanto los de carácter cognitivo y sociocognitivo como los de orientación más socio-cultural. De acuerdo con Castelló, Bañales, y Vega (2010), dichos enfoques se diferencian, desde el punto de vista teórico, en el valor que otorgan a los factores metacognitivos, motivacionales y contextuales implicados en la generación de textos, $\mathrm{y}$, desde el punto de vista metodológico, en los procedimientos de recogida y análisis de datos utilizados durante la realización de tareas de escritura de forma individual o, alternativamente, en situación de colaboración.

Desde una perspectiva cognitiva y sobre la base del modelo pionero propuesto por Flower y Hayes (1980), las propuestas procesuales más recientes (e.g., Alamargot \& Chanquoy, 2001; Roussey \& Piolat, 2005) señalan que la composición de textos, además de una práctica comunicativa, ha de entenderse como un problema complejo que los escritores han de resolver mediante la activación de procesos de regulación descendente, o de arriba-abajo (planificación), y ascendente, o de abajo-arriba (revisión). Mientras que los primeros implican el establecimiento de distintos tipos de objetivos y sub-objetivos (de contenido, retóricos, etc.) que permiten al escritor controlar y coordinar la producción textual de forma más o menos integrada (Carey, Flower, Hayes, Schriver, \& Haas, 1989; Torrance \& Galbraith, 2006), los procesos de revisión le permiten controlar el logro de los objetivos previamente establecidos por medio de actividades de detección, diagnóstico y resolución de problemas tanto a nivel local como global (Hayes, Flower, Schriver, Stratman, \& Carey, 1987; Midgette, Haria, \& McArthur, 2008). Ambos tipos de procesos no tienen un 
carácter lineal, sino más bien recursivo, y su eficacia de cara a la producción del texto depende del grado de competencia que tenga el escritor para gestionarlos

Sin embargo, las aportaciones de carácter cognitivo resultan limitadas cuando se trata de explicar los procesos de regulación en función de variables tales como la motivación para escribir o el contexto en el que los escritores componen sus textos. Tal empresa se ha llevado a cabo por medio de un conjunto de investigaciones (e.g., Graham \& Harris, 2000; Zimmerman \& Kitsantas, 2007) que tienen como denominador común la consideración de la escritura como una actividad socio-cognitiva en la que las habilidades de regulación se adquieren de forma secuencial y a diversos niveles (cognitivos, conductuales, afectivos, etc.), pasando de estar socialmente controladas y motivadas (a través de procesos de observación y emulación) a ser finalmente auto-controladas y auto-motivadas (a través de procesos de autorregulación) (véase Castelló, Bañales, \& Vega, 2010). No obstante, una de las limitaciones de los estudios realizados bajo esta perspectiva teórica es que sus resultados y conclusiones, al estar basados fundamentalmente en el análisis de tareas de escritura realizadas en contextos de educación primaria y secundaria, no se pueden hacer extensivos con garantías a otros ámbitos caracterizados por tareas más complejas, como es el caso de la universidad. Por otra parte, se trata de una línea de investigación que, al igual que la perspectiva cognitiva anteriormente citada, se ha limitado al análisis de procesos de composición individuales, dejando de lado los procesos de co-regulación que aparecen cuando la composición de textos se entiende como una actividad dialógica y situada, llevada a cabo por los miembros de una comunidad de discurso en un contexto cultural determinado. El análisis de estos procesos se suele abordar desde la perspectiva socio-cultural.

Desde esta perspectiva se postula que la co-regulación es el mecanismo que permite al aprendiz apropiarse de las destrezas y otras herramientas culturales que le proporciona la interacción con el docente $\mathrm{u}$ otros estudiantes más avanzados (plano inter-psicológico), o bien (plano intra-psicológico) con otras voces y herramientas ya interiorizadas (Castelló, 2007; Flower, 1994) y utilizarlas de forma autónoma para la construcción textual (Englert, Mariage, \& Dunsmore, 2006). Sobre estas premisas, se ha llevado a cabo un buen número de investigaciones orientadas a mostrar cómo la co-regulación se despliega en los procesos de planificación y revisión colaborativas entre estudiantes universitarios, y a clarificar cómo los procesos de regulación aparentemente individuales llevados a cabo por escritores expertos durante la realización de tareas auténticas (e.g., composición de artículos científicos) se hallan realmente mediados por los criterios imperantes en las comunidades de discurso en los que la actividad se encuentra inserta (véase Castelló et al., 2010).

Con independencia de que se conciba como una práctica cognitivo-individual o como una práctica social e institucional, y que se analice desde perspectivas cognitivas, socio-cognitivas o socio-culturales, la producción de textos académicos requiere como una de sus competencias básicas el que los estudiantes se familiaricen, como mínimo, con el carácter recursivo del proceso de composición y adquieran cierto nivel de destreza en el manejo y coordinación 
de las actividades implicadas en los subprocesos de planificación, formulación y revisión, así como en la selección, interpretación y utilización eficaz de las fuentes empleadas (Kruse, 2013).

Sobre esta base, y dado el reducido número de investigaciones de largo alcance sobre las prácticas y procesos de escritura académica en la universidad española (véase el primer artículo de este monográfico), con el presente estudio pretendemos conocer cuáles son las percepciones de profesores y estudiantes respecto a los procesos implicados en la elaboración de textos académicos en general. Subrayamos el carácter 'general' de nuestro análisis porque, de acuerdo con la escala del cuestionario utilizada (véase más abajo), no nos planteamos como objetivo explorar la diversidad de procesos de composición que cabría esperar al abordar géneros textuales específicos. Esta 'diversidad' de procesos vendría dada no sólo porque las convenciones discursivas propias de cada género han de entenderse como las formas en que los distintos saberes son vehiculados sino, y quizá de manera más fundamental, como instrumentos que permiten construir el conocimiento y establecer relaciones con las actividades en que éste se desarrolla (Camps \& Castelló, 2013).

De acuerdo con ello, en este estudio se plantean los siguientes objetivos:

(1) Identificar las percepciones de estudiantes y profesores de distintas universidades españolas sobre los procesos de composición de textos académicos.

(2) Valorar hasta qué punto y en qué procesos específicos estas percepciones son compartidas por ambos grupos.

\section{Método}

El diseño del estudio es descriptivo y transversal, y en él se ha utilizado una metodología cuantitativa.

\section{Participantes}

Aunque el proyecto descrito en el primer artículo de este monográfico incluye una muestra de 279 profesores y 1,044 estudiantes de diversas disciplinas en los niveles de grado y postgrado de nueve universidades españolas, en el presente estudio nos hemos centrado en el análisis de las respuestas proporcionadas por una sub-muestra de estudiantes $(n=733)$ y profesores $(n=230)$ de los grados de ciencias sociales y jurídicas, artes y humanidades.

Las razones para la selección de esta sub-muestra se detallan a continuación. En la muestra total de estudiantes, y en correspondencia con las proporciones de la población de estudiantes universitarios españoles en el año 2012 (Ministerio de Educación Cultura y Deporte (MECD), 2012), nos encontramos con que el 90\% cursaba estudios de grado; el 7.8\%, de máster; y el 2.3\%, de doctorado. En una primera aproximación a los datos recogidos, observamos que las actividades relacionadas con la escritura académica variaban ostensiblemente según el nivel 
académico implicado. Antes de proceder al análisis estadístico de los datos se comprobó que estos cumplen con el criterio de homogeneidad mediante la prueba de Levene, encontrando resultados satisfactorios en todos los casos (todos los valores $F(2,1159)<1.93, p>.14)$. A continuación se aplicó un análisis multivariado de la varianza (MANOVA) tomando como factor el tipo de estudios (Grado, Máster, Doctorado) y como variable dependiente $(V D)$ las respuestas a los ítems 2A, 2B, 2C, 2D y 2E (Kruse, 2013). Los resultados obtenidos muestran la existencia de diferencias significativas entre los tres niveles implicados en el estudio $(F(10,2310)=2.774, p=.002)$. Las diferencias se debían principalmente a que el promedio del número de horas semanales dedicadas a la escritura en los estudios de grado $(\bar{x}=3.23)$ era inferior $(p<.01)$ al que se producía en el nivel de máster $(\bar{x}=3.51)$ y de doctorado $(\bar{x}=3.81)$, mientras que la diferencia entre estos dos colectivos no resultaba significativa.

Esta diferencia en el número de horas dedicadas a la escritura puede suponer cambios sustantivos en la naturaleza y distribución de los procesos en los que estamos interesados. Para evitar la heterogeneidad descriptiva que ello supondría, decidimos restringir nuestro análisis a los 1,030 estudiantes de grado que respondieron al cuestionario con una tasa de respuestas válidas igual o superior al $60 \%$ (14 participantes resultaron eliminados por no cumplir con este criterio). Los estudiantes de máster y doctorado $(n=118)$ fueron excluidos del análisis. Por tanto, los resultados de nuestro estudio quedan circunscritos a la etapa inicial de la formación universitaria española, etapa en la que se suele dedicar una proporción de tiempo relativamente baja a la elaboración de textos académicos.

Una vez seleccionada la sub-muestra de estudiantes de grado, realizamos un nuevo MANOVA sobre las variables que codifican la asignación de tareas (item 2: A-E, véase Kruse, 2013) para comprobar si existían diferencias en estas variables asociadas a las diferentes áreas de estudio a las que pertenecían los estudiantes seleccionados. Los resultados mostraron que existían diferencias significativas a nivel global entre las diferentes áreas (Wilks $\lambda=.874, F(15,2860)=9.509$, $p<.001)$. Las comparaciones post-hoc por pares indicaron la existencia de dos agrupaciones dentro de ellas. Por un lado, se encontraba el área de ciencias sociales y jurídicas, que se agrupaba con el área de artes y humanidades; y, por el otro, el área de ciencias de la salud, que se agrupaba con ingenierías y arquitectura. No se hallaron diferencias significativas entre los componentes de cada agrupación $(p>37)$, pero sí entre los componentes de agrupaciones diferentes $(p<.001)$, debido a que las actividades de escritura son sistemáticamente más frecuentes en las CC sociales y jurídicas que en las CC de la salud, ingenierías y arquitectura. Por esta razón, para constituir la muestra final de estudiantes que se sometió a análisis seleccionamos a los 733 estudiantes de CC sociales y jurídicas $(n=703)$ y los de humanidades $(n=30)$, que en conjunto suponen el $70.21 \%$ del total de participantes que estudian grado.

Respecto a la muestra de profesores, seleccionamos a los 230 profesores (41 de artes y humanidades y 189 de CC sociales, es decir, el $82.4 \%$ de la muestra total de este colectivo) que pertenecían a las mismas áreas de estudio que los estudiantes. 


\section{Materiales}

Para llevar a cabo el principal objetivo del estudio utilizamos la escala 3 ('El proceso de composición'), que se incluye en el cuestionario Encuesta Europea sobre la Escritura Académica (EEEA) (en su versión inglesa: European Writing Survey, EUWRIT) (Chitez, Kruse, \& Castelló, 2015; Kruse, 2013; Kruse $\&$ Chitez, 2012), cuyas características se presentan en el primer artículo de este monográfico. La escala utilizada, al igual que todo el cuestionario, tiene dos versiones, cada una de las cuales está destinada a captar las percepciones de los estudiantes, por un lado, y de los profesores, por otro, respecto a los mismos aspectos de la escritura.

Aunque en el cuestionario original aplicado a la muestra de estudiantes se presentaba un total de 12 ítems dentro de la escala mencionada, restringimos el análisis a los seis primeros por ser éstos los que se hallan directamente relacionados con las conductas asociadas al proceso de elaboración de textos. Estos ítems describen aspectos relacionados con los diferentes subprocesos de composición, según han sido establecidos por los modelos clásicos de corte cognitivo (e.g., Flower \& Hayes, 1980): planificación (items 1-3), formulación (item 4) y revision (ítems 5-6). Por su parte, los ítems descartados (del 7 al 12) se refieren a valoraciones de los estudiantes respecto a diferentes componentes exteriores al proceso de composición como tal: profesores, universidad y actitud frente al plagio. Por su parte, el cuestionario aplicado a los profesores sigue el mismo patrón que el de los estudiantes, con la particularidad de que las respuestas a los ítems utilizados en este caso se basan en inferencias sobre la conducta de los alumnos a partir de 'su propia experiencia' como docentes. Es éste un aspecto problemático de los datos, como veremos más adelante, ya que no es posible garantizar que las valoraciones realizadas por el profesorado sean el resultado del conocimiento directo de las distintas fases de elaboración textual por parte de los estudiantes, sino más bien de su evaluación de los textos ya producidos. Por tanto, debemos interpretar los resultados relativos a esta parte de la muestra como fenómenos relacionados con el campo de la opinión más que como una valoración directa de hechos observados a través del contacto con el estudiante y su labor como escritor.

\section{Análisis de los datos}

Los datos procedentes de los cuestionarios han sido analizados en función de las diferencias entre alumnos y profesores, por un lado, y de los patrones de correlación entre los ítems en cada uno de los dos grupos, por otro. La comparación de las valoraciones de los estudiantes y los profesores, además de proporcionar información sobre los componentes descriptivos de los dos actores principales del proceso de escritura académica, puede servir para comprender algunos fenómenos que se producen en el contexto académico y educativo de la universidad española actual. En este sentido, hemos examinado las diferencias alumno/profesor en cada uno de los ítems analizados con la finalidad de clarificar las particularidades de cada muestra, y, de forma complementaria, aportamos los 
resultados de un análisis discriminante que nos ha permitido señalar las diferencias más relevantes a la hora de caracterizar a cada grupo. Por otra parte, hemos llevado a cabo un análisis de correlaciones para analizar la posible asociación entre unos ítems y otros en cada muestra, y para entender las concepciones globales de profesores y estudiantes respecto a los procesos de composición. Esta asociación queda cualificada por medio de un análisis factorial que nos ha permitido establecer las variables latentes que subyacen a las respuestas de ambos colectivos.

\section{Resultados}

\section{Análisis de las diferencias entre alumnos y profesores}

En la Tabla 1 se muestran los promedios y desviaciones típicas de las estimaciones ofrecidas por los estudiantes y los profesores en cada uno de los ítems, junto con el nivel de significación de las diferencias.

Una primera aproximación a estos datos indica que tanto profesores como alumnos muestran una valoración promedio que, como mínimo, se ubica muy próxima al punto medio de la escala, pero que, en general, alcanza una valoración superior. La valoración más baja corresponde a la que ofrecen los profesores respecto a la planificación de los textos por parte de los estudiantes $(\bar{x}=2.69$; $D T=1.07)$ y la máxima, a la que los propios estudiantes atribuyen a la lectura de los documentos antes de acometer el proceso de escritura $(\bar{x}=3.97 ; D T=0.94)$. No hay, por tanto, valoraciones que aparezcan en el extremo negativo de la escala $\mathrm{y}$, por otra parte, las valoraciones positivas tampoco alcanzan valores muy extremos.

El análisis de las diferencias entre alumnos y profesores indica que los primeros otorgan una puntuación significativamente mayor a los ítems 1 ' $\ldots$

Tabla 1. Medias (desviaciones típicas) de las valoraciones de alumnos y profesores sobre los diferentes procesos implicados en la escritura. Valores de la prueba de significación de las diferencias y el valor del tamaño del efecto $\left(\eta^{2}\right)$.

\begin{tabular}{|c|c|c|c|c|c|}
\hline Ítem & Profesor & Estudiante & $F(1,957)$ & $p$ & $\eta 2$ \\
\hline 1.... plani & 2.69 & 3.76 & 209.37 & .000 & .180 \\
\hline $\begin{array}{l}\text { espontáneamente y se dejan llevar por } \\
\text { el propio texto. }\end{array}$ & $3.26(1.09)$ & $2.95(1.11)$ & 14.18 & .000 & .015 \\
\hline $\begin{array}{l}\text { 3. ... realizan todas las lecturas antes de } \\
\text { empezar a escribir. }\end{array}$ & $2.76(1.08)$ & $3.97(0.92)$ & 277.16 & .000 & .225 \\
\hline $\begin{array}{l}4 \ldots \text { dejan que sus ideas cambien }[\ldots] \text { a } \\
\text { medida que van escribiendo sus textos }\end{array}$ & $3.54(0.98)$ & $3.68(0.93)$ & 3.75 & .053 & .004 \\
\hline $\begin{array}{l}\text { 5.... la revisión es una parte esencial de } \\
\text { la escritura de los estudiantes. }\end{array}$ & $3.61(1.40)$ & $3.6(0.97)$ & 0.02 & .895 & .000 \\
\hline $\begin{array}{l}6 . . . \text { comentan sus textos con alguien y } \\
\text { reciben feedback para mejorarlos. }\end{array}$ & $2.81(1.11)$ & $2.7(1.18)$ & 1.56 & .212 & .002 \\
\hline
\end{tabular}


planifican antes de escribir un texto' y 3 ' ... realizan todas las lecturas antes de empezar a escribir', mientras que los profesores alcanzan una puntuación promedio superior a los estudiantes en el ítem 2 '... empiezan a escribir espontáneamente y se dejan llevar por el propio texto'. Sin embargo, en todos los casos, el tamaño del efecto observado resulta bastante moderado. Por otra parte, en los ítems 4, 5 y 6 no se observan diferencias significativas.

De todo ello podemos inferir que existe cierta similitud en la valoración de los procesos de escritura por parte de alumnos y profesores y que esta valoración, en términos generales, gira alrededor del punto medio de la escala (3: 'no estoy seguro'), con la única salvedad de la valoración del ítem 3 por parte de los estudiantes, que prácticamente alcanza el punto 4 ('de acuerdo').

\section{Análisis discriminante}

Por medio de la técnica del análisis discriminante, un procedimiento estadístico que permite clasificar un conjunto de elementos en dos o más categorías sobre la base de los rasgos que los caracterizan (Stevens, 2009), procedimos a seleccionar aquellos ítems cuyo coeficiente estandarizado mostraba un valor absoluto superior a 0.5 (ver Tabla 2). Como resultado, identificamos dos únicos ítems, el número 3 'realizan todas las lecturas antes de empezar a escribir' y el número 1 'planifican antes de escribir un texto', a partir de los cuales se pudo discriminar correctamente el $83.6 \%$ de las puntuaciones de los alumnos y profesores, según el procedimiento 'let-one-out'.

Por otra parte, los datos indican que existe acuerdo entre alumnos y profesores respecto a que los primeros (a) se dejan llevar en sus ideas por el desarrollo del propio texto, (b) comentan sus textos con alguien y reciben feedback para mejorarlos, y (c) consideran que la revisión es una parte esencial de sus procesos de escritura.

\section{Análisis de correlación}

Los resultados del análisis de correlación de Pearson entre los ítems del grupo de estudiantes ha dado como resultado un alto número de correlaciones significativas

Tabla 2. Coeficientes estandarizados de las funciones discriminantes canónicas.

Ítem Función 1

1.... planifican antes de escribir un texto.

2.... empiezan a escribir espontáneamente y se dejan llevar por el propio texto.

3.... realizan todas las lecturas antes de empezar a escribir.

4.... dejan que sus ideas cambien [] a medida que van escribiendo sus textos

5.... la revisión es una parte esencial de la escritura de los estudiantes.

6 .... comentan sus textos con alguien y reciben feedback para mejorarlos. 
Tabla 3. Correlaciones entre procesos de escritura en las muestras de alumnos y profesores.

\begin{tabular}{|c|c|c|c|c|c|}
\hline & 1 & 2 & 3 & 4 & 5 \\
\hline Item & Estudiantes & & & & \\
\hline 2 & $-.211 * *$ & & & & \\
\hline 3 & .095 & $-.214 * *$ & & & \\
\hline 4 & -.118 & $-.164 *$ & $.250 * *$ & & \\
\hline 5 & $.144^{*}$ & $-.339 * *$ & $.370 * *$ & $.278 * *$ & \\
\hline 6 & $.243^{* *}$ & $-.195 * *$ & $.350 * *$ & $.169 *$ & $.439 * *$ \\
\hline & Profesores & & & & \\
\hline 2 & $-.529 * *$ & & & & \\
\hline 3 & $.313^{* *}$ & $-.193 * *$ & & & \\
\hline 4 & .008 & $.146^{* *}$ & -.068 & & \\
\hline 5 & $.351 * *$ & $-.123 * *$ & $.273 * *$ & .039 & \\
\hline 6 & $.175^{* *}$ & -.028 & $.154 * *$ & .044 & $.278 * *$ \\
\hline
\end{tabular}

Nota: $* * p<.001 ; * p<.05$.

Ítems

1.... planifican antes de escribir un texto.

2 .... empiezan a escribir espontáneamente y se dejan llevar por el propio texto.

3.... realizan todas las lecturas antes de empezar a escribir.

4.... dejan que sus ideas cambien o se vayan modificando a medida que van escribiendo sus textos

$5 . .$. la revisión es una parte esencial de la escritura de los estudiantes.

6 .... comentan sus textos con alguien y reciben feedback para mejorarlos.

entre los seis ítems del cuestionario (ver Tabla 3), lo que indica que las diferentes conductas reflejadas en ellos forman parte de una estructura integrada de acciones que conduce a la producción de un texto. El patrón de correlaciones parece estar organizado por la pertenencia (1) al grupo de ítems que podríamos denominar más 'normativizado' o top/down (arriba-abajo), ya que denota conductas consideradas 'más canónicas', de acuerdo con los modelos clásicos de composición (e.g., Flower \& Hayes, 1980); o (2) al grupo de ítems de carácter 'menos canónico' o bottom/up (abajo-arriba), que denota conductas de carácter más 'emergentista' o 'constitutivista' (e.g., Galbraith, 1999). Los ítems de carácter más canónico serían el número 1 '.. planifican antes de escribir un texto', el número 3 ' $\ldots$ realizan todas las lecturas antes de empezar a escribir', el número 5 '. . . la revisión es una parte esencial de la escritura de los estudiantes' y el número 6 ' $\ldots$ comentan sus textos con alguien y reciben feedback para mejorarlos'. Por su parte, los ítems que implican procesos de abajo-arriba incluirían el número 2 '... empiezan a escribir espontáneamente y se dejan llevar por el propio texto' y el número 4 ' $\ldots$ dejan que sus ideas cambien o se vayan modificando a medida que van escribiendo sus textos'.

La existencia de estos dos grupos viene avalada por el hecho de que los ítems de cada uno tienden a mantener correlaciones positivas entre sí y negativas con los del grupo opuesto. Así el ítem que implica planificación (ítem 1) mantiene correlaciones positivas con los que refieren conductas de revisión del texto (ítems 5 y 6) y con la revisión bibliográfica previa (ítem 3); y, por otro lado, 
también existen correlaciones positivas entre los ítems que expresan estrategias o acciones que tienen un carácter menos canónico: comenzar a escribir espontáneamente y dejarse llevar por el texto (ítems 2 y 4 ). Por lo que respecta a las correlaciones negativas, la más alta en valor absoluto se da entre los ítems 1 y 2, pero resulta trivial ya que denota conductas conceptualmente opuestas. Finalmente, el ítem 4 ('mis ideas cambian mientras voy redactando el texto') que, como dijimos, correlaciona significativamente con el ítem 2 dentro de su grupo, no mantiene correlaciones significativas con el resto de ítems del grupo 'canónico'.

Con respecto a las respuestas de los profesores, se observa un patrón de correlaciones similar al de los estudiantes, aunque con algunas diferencias (ver Tabla 3). Las correlaciones entre los ítems del grupo 'canónico' son todas positivas, superiores a cero y alcanzan significación estadística, con la única excepción del coeficiente entre los ítems 1 y 3 , debido posiblemente a que este último ítem ('lectura previa de textos') implica para los profesores un conjunto distinto de destrezas de las que implica para los alumnos. Sin embargo, de forma sorprendente, el patrón de correlaciones positivas observado entre los estudiantes para el grupo de ítems 'menos canónico' no se reproduce en el grupo de los profesores. En este caso, obtenemos una correlación significativa, pero negativa, entre los ítems 2 ('empezar a escribir de inmediato') y 4 ('mis ideas cambian mientras escribo') aunque ciertamente es algo baja $(r=-.164)$. Posiblemente, al igual que en el ítem 3, esta anomalía se debe a que los profesores interpretan el ítem 4 de una forma diferente a la de los estudiantes.

\section{Análisis factorial}

Las respuestas a los seis ítems fueron sometidas a un análisis factorial de componentes principales con el objetivo de encontrar las dimensiones que pueden organizar y resumir las respuestas de los estudiantes y profesores. Es importante señalar que el objetivo de este análisis es el de resumir los patrones de variación de los datos directos y así favorecer una comparación simplificada (Landau \& Everitt, 2004; Stevens, 2009). No debe confundirse este objetivo con el del análisis factorial exploratorio, que persigue la identificación de variables latentes que pueden subyacer a los datos. Los resultados del análisis sobre las respuestas de los estudiantes arroja un total de tres factores que logran explicar el $69 \%$ de la varianza total de las puntuaciones de este grupo.

En la Tabla 4 se muestran los componentes rotados con el método VARIMAX para la muestra de estudiantes. Los tres factores resultantes son: 'uso de información externa' (F I), 'organización interna del proceso' (F II) y 'modificabilidad' (F III). El factor I agrupa los ítems 3, 5 y 6, que son los que se refieren al uso de fuentes de información externa para incorporarla en el trabajo. Tanto las lecturas como los procesos de revisión (donde, entre otros aspectos, se establece la adecuación del texto al lector) y el uso del feedback se refieren a una agencia externa, diferente del propio escritor, como condicionante y referente de los contenidos y estructura del texto. 
Tabla 4. Análisis factorial de componentes principales sobre las valoraciones de los procesos de escritura por parte de los estudiantes.

\begin{tabular}{|c|c|c|c|}
\hline \multirow[b]{2}{*}{ Ítem } & \multicolumn{3}{|c|}{ Factor } \\
\hline & $\begin{array}{l}\text { I } \\
\text { Información } \\
\text { Externa }\end{array}$ & $\begin{array}{l}\text { II } \\
\text { Organización } \\
\text { Interna }\end{array}$ & $\begin{array}{c}\text { III } \\
\text { Modificabilidad }\end{array}$ \\
\hline 1.... planifican antes de escribir un texto. & .301 & .819 & .096 \\
\hline $\begin{array}{l}2 . . . \text { empiezan a escribir espontáneamente } \\
\text { y se dejan llevar por el propio texto. }\end{array}$ & .052 & -.871 & .135 \\
\hline $\begin{array}{l}\text { 3... realizan todas las lecturas antes de } \\
\text { empezar a escribir. }\end{array}$ & .519 & .338 & -.220 \\
\hline $\begin{array}{l}\text { 4. ... dejan que sus ideas cambien o se } \\
\text { vayan modificando a medida que van } \\
\text { escribiendo sus textos }\end{array}$ & .024 & -.038 & .974 \\
\hline $\begin{array}{l}\text { 5... la revisión es una parte esencial de la } \\
\text { escritura de los estudiantes. }\end{array}$ & .717 & .235 & .100 \\
\hline $\begin{array}{l}6 . \text {... comentan sus textos con alguien y } \\
\text { reciben feedback para mejorarlos. }\end{array}$ & .782 & -.118 & .035 \\
\hline
\end{tabular}

El factor II, 'organización interna del proceso', agrupa los ítems 1 y 2. El primero alude de forma explícita a la planificación y su asociación con el ítem 2 , que refiere de forma negativa la espontaneidad en el inicio de la composición y la indeterminación en el proceso de formulación. La composición de éste factor sugiere la existencia de una dimensión de planificación/improvisación. Los estudiantes que puntúen alto en este factor tenderán a valorar mucho la planificación y a rechazar la idea de dejarse llevar por el texto. Finalmente el factor III, al que hemos denominado 'modificabilidad', está compuesto por un único ítem: 'dejan que sus ideas cambien o se vayan modificando a medida que van escribiendo sus textos'. Los estudiantes parecen creer que existe una dimensión independiente de las anteriores que codifica la tendencia a dejarse influir por la dinámica del desarrollo textual, abandonando total o parcialmente los presupuestos iniciales.

En la Tabla 5 se muestra el resultado del análisis factorial de componentes principales sobre las percepciones de los profesores acerca del proceso de escritura de sus estudiantes (componentes rotados por el método VARIMAX). Este análisis arroja de nuevo como resultado tres factores que logran explicar el $70.2 \%$ de la varianza total de las puntuaciones del grupo. Sin embargo, la estructura de los factores obtenidos difiere de la observada para la muestra de estudiantes.

Al primer factor lo hemos denominado 'uso de información externa', y agrupa los ítems 3, 5 y 6 . Al igual que sucedió en el estudio sobre las valoraciones de los estudiantes, la carga principal de este factor codifica el uso e incorporación de información procedente de agentes diferentes al propio escritor durante el proceso de composición textual.

El segundo factor, al que denominamos de la misma manera que su homólogo en el estudio factorial sobre los estudiantes, 'organización interna', agrupa el ítem 4 
Tabla 5. Análisis factorial de componentes principales sobre las valoraciones de los procesos de escritura por parte de los profesores.

\begin{tabular}{|c|c|c|c|}
\hline & \multicolumn{3}{|c|}{ Factor } \\
\hline & $\begin{array}{c}\text { I } \\
\text { Información. } \\
\text { Externa. }\end{array}$ & $\begin{array}{c}\text { II } \\
\text { Organización } \\
\text { Interna. }\end{array}$ & $\begin{array}{c}\text { III } \\
\text { Espontaneidad }\end{array}$ \\
\hline 1.... planifican antes de escribir un texto. & .26 & -.741 & .356 \\
\hline $\begin{array}{l}2 . . . \text { empiezan a escribir espontáneamente } \\
\text { y se dejan llevar por el propio texto. }\end{array}$ & -.103 & .037 & -.936 \\
\hline $\begin{array}{l}\text { 3... realizan todas las lecturas antes de } \\
\text { empezar a escribir. }\end{array}$ & .719 & .158 & .083 \\
\hline $\begin{array}{l}4 \ldots \text { dejan que sus ideas cambien }[\ldots] \text { a } \\
\text { medida que van escribiendo sus textos }\end{array}$ & .335 & .714 & .276 \\
\hline $\begin{array}{l}\text { 5... la revisión es una parte esencial de la } \\
\text { escritura de los estudiantes. }\end{array}$ & .677 & .113 & .367 \\
\hline $\begin{array}{l}6 . \text {... comentan sus textos con alguien y } \\
\text { reciben feedback para mejorarlos. }\end{array}$ & .825 & -.221 & -.007 \\
\hline
\end{tabular}

('dejan que sus ideas cambien ...'), con carga positiva, y el ítem 2 ('planificación'), con carga negativa. La carga positiva del ítem, que indica espontaneidad en la composición del texto, en combinación con la carga negativa de la planificación indica probablemente la creencia por parte de los profesores de que aquellos alumnos que se dejan llevar por la espontaneidad y las circunstancias presentes en el momento de iniciar la escritura no suelen ser escritores sistemáticos y previsores. Por otra parte, este factor tiene una estructura similar al hallado en la muestra de estudiantes, aunque el signo de las cargas factoriales sea opuesto. En este caso, los estudiantes que puntúen alto en este factor tenderán a elaborar pocos planes previos a la escritura y es probable que se dejen llevar por la dinámica de la creación textual. Finalmente, el análisis muestra la existencia de un factor 3 que está compuesto únicamente por el ítem $2, ‘$. empiezan a escribir espontáneamente y se dejan llevar por el propio texto'. Este factor lo hemos denominado 'espontaneidad' y es interpretable como una creencia por parte de los profesores respecto a una dimensión que indica cierta actitud espontánea de algunos alumnos en el inicio y desarrollo del proceso de escritura académica.

\section{Discusión}

El presente estudio constituye una primera aproximación al análisis de las percepciones de estudiantes y profesores respecto a los procesos implicados en la escritura de textos académicos en la universidad española. La exploración descriptiva y relacional de los datos nos ha permitido ahondar en la multiplicidad de dimensiones y conexiones que parecen estar presentes en la formulación de dichas percepciones.

En primer lugar, la comparación de medias y el análisis discriminante han mostrado que los profesores y estudiantes se diferencian principalmente en dos 
consideraciones respecto a la naturaleza de las actividades asociadas a la escritura: (1) la planificación previa a la elaboración de un texto; y (2) la lectura previa de las referencias necesarias antes de iniciar el proceso de composición. Los estudiantes aseguran realizar estos procesos con más frecuencia de la que parecen percibir sus profesores.

Lo realmente relevante de estas diferencias es que se refieren a actividades realizadas con antelación al propio acto de escribir (planificación y lectura de textos), y no tanto al propio proceso de escritura o al producto final de dicho proceso. $\mathrm{Si}$, como hemos señalado más arriba, es probable que los profesores construyan sus percepciones respecto a la naturaleza de los procesos de composición de los estudiantes a partir de los textos que éstos les entregan, las diferencias que estamos mostrando indicarían, por tanto, disparidades entre los informes del alumnado, que obviamente poseen un carácter subjetivo pero que están basados en un contacto directo con la realidad evaluada, y una concepción más especulativa, que es la que el profesorado genera a partir de sus inferencias. A tenor de esta interpretación, cabría suponer que, en general, los profesores no se encuentran totalmente satisfechos con el producto final que les entregan los alumnos y que infieren, como causa, una deficiencia por parte de éstos en los procesos de lectura previa y planificación, procesos que, de acuerdo con determinados modelos que enfatizan el papel del conocimiento y organización del contenido así como de la intertextualidad (véase, por ejemplo, Deane et al., 2008; Flower, 1994), serían esenciales para una eficaz elaboración de textos. Por otra parte, también cabría especular que la diferencia entre estudiantes y profesores puede tener su origen no tanto en el distinto grado de cercanía de ambos colectivos al proceso de composición de los estudiantes cuanto en su distinta valoración de la calidad final de los textos producidos. Es posible que los estudiantes consideren que sus escritos tienen una calidad superior a la que le atribuyen los profesores y que, por consiguiente, difieran de ellos en la valoración de algunos de los procesos que dan lugar a la composición de dichos textos. Desafortunadamente, no se dispone en el cuestionario de ningún ítem que sirva para obtener una valoración directa de la calidad de los textos producidos.

Por otra parte, la coincidencia de ambos grupos en sus percepciones respecto a la modificación de las ideas en el decurso de la composición y al papel que la revisión y el feedback desempeñan en la producción de textos puede interpretarse como un reflejo de que estos procesos se consideran generalmente como inherentes o esenciales al acto de escribir, aunque con diversos grados de intensidad (véase Fayol, Alamargot, \& Berninger, 2012). Galbraith (1999, 2009), por ejemplo, ha sugerido que, aunque la investigación derivada de los modelos clásicos de composición (e.g., Bereiter \& Scardamalia, 1987; Flower \& Hayes, 1980) concibe la escritura como un proceso de arriba-abajo en el que el contenido previamente planificado se plasma por medio de palabras en la página, el acto de escribir ha de contemplarse realmente como un proceso de 'constitución del conocimiento' en el que la creación del contenido es determinado parcialmente por procesos de arribaabajo, pero también por episodios de procesamiento lingüístico (abajo-arriba). Desde esta perspectiva, tanto la estructura como el significado de las frases se 
desarrollan mientras éstas se producen y, posteriormente, son reconfigurados por procesos de revisión (Hayes, 2012). Los profesores y estudiantes parecen coincidir en sus percepciones sobre estas características de la escritura, y ello podría ayudar a entender la razón por la que los primeros, aunque tengan una opinión desfavorable respecto a la actividad de planificación de los segundos, no cuestionen, sin embargo, su actividad como revisores. Es posible que consideren que los procesos de revisión son más inherentes y, por tanto, menos opcionales al acto de escribir que los de planificación.

Sin embargo, a pesar de las coincidencias entre los dos grupos que aparecen en los datos anteriores, el análisis de correlaciones indica que su respuesta al ítem 4 ('las ideas se modifican en el decurso de la escritura') no es equivalente. Si bien en ambos colectivos este ítem correlaciona de forma negativa con los ítems del grupo 'canónico' (planificar, realizar lecturas previas, revisar los textos y recibir feedback), su correlación con el ítem 2 ('empezar a escribir de inmediato'), dentro del grupo 'no canónico', resulta positiva en el caso de los estudiantes pero negativa, en el de los profesores. Esta diferencia no sería sino una muestra más de la diferente interpretación que realizan ambos colectivos del proceso de composición de textos académicos. Se podría pensar que si los profesores tienden a concebir este proceso como una actividad que implica una continua reelaboración de ideas orientada a 'transformar el conocimiento' y que es, por tanto, incompatible con un tipo de escritura espontánea e inmediatista, los estudiantes contemplarían la tarea sólo como el cumplimiento de un conjunto de requisitos de un determinado profesor, y se dejarían llevar de forma inmediata por el dinamismo inherente al acto de escribir hasta que, utilizando un procedimiento sólo orientado a 'mostrar el conocimiento', hubiesen agotado su repertorio de ideas sobre el tema (Bereiter \& Scardamalia, 1987).

Finalmente, la estructura factorial de los ítems es diferente en los estudiantes y en los profesores. Aunque existe un factor común que hemos denominado 'uso de información externa', que agrupa tres de los seis ítems del sub-cuestionario, el resto de ítems se agrupa de forma diferente en cada muestra. Mientras que entre los estudiantes existe una agrupación de espontaneidad y planificación, quedando aparte la modificabilidad, en el caso de los profesores es la espontaneidad la que funciona de forma diferente, produciéndose una agrupación entre modificabilidad y planificación.

Aunque no es sencillo proponer una interpretación de esta diferencia, cabría suponer que entre los estudiantes la asociación entre planificación y espontaneidad tiene como base el comienzo de la formulación textual: la planificación no sería sino una demora en el inicio de la formulación. En el grupo de los profesores, por el contario, la asociación entre planificación y modificación de ideas según se avanza en la composición no tendría esta dimensión temporal, sino más bien un carácter estratégico. Para los profesores, si el estudiante se deja llevar por los avatares de la composición textual, es porque carecería de una representación del contenido del texto en forma de ideas previas precisas y bien estructuradas que no se han formulado en la (ausente) fase de planificación. Por tanto, aquellos estudiantes que realizan un proceso de planificación serían menos 
proclives a dejar que el desarrollo del texto vaya modificando sus ideas. La espontaneidad es un rasgo que, en principio, no tiene una asociación evidente con este componente estratégico y, por ello, se constituye como un factor independiente.

\section{Conclusiones}

El estudio muestra que las respuestas de profesores y estudiantes se encuentran muy próximas a, o por encima de, 3, lo que indica que, con carácter general, ambos colectivos valoran de forma razonablemente positiva los procesos de escritura académica en la universidad. Dicho esto, conviene señalar, sin embargo, que el patrón de valoraciones es bastante complejo, pues ambos colectivos sólo coinciden parcialmente en sus percepciones.

Aunque las estimaciones de profesores y estudiantes son similares en lo que respecta a la modificación de las ideas a lo largo de la composición (aunque este proceso parece entenderse de forma diferente por profesores y alumnos) y al valor atribuido a los procesos de revisión y de feedback, se diferencian de forma clara en la valoración atribuida a la lectura de los materiales necesarios para la realización de la tarea y a los procesos de planificación previos a la escritura del texto.

Estas diferencias parecen confirmar una vez más el carácter reproductivo, más que epistémico, de los procesos de composición en la universidad española, y estarían en línea con los resultados de otros estudios en este monográfico en los que se documenta que la escritura en este contexto se suele utilizar más como como un mero registro del conocimiento ya establecido que como una herramienta que favorece el proceso de elaboración de nuevo conocimiento y posibilita su comunicación (véase Corcelles, Oliva, Castelló, \& Milian, 2015).

En este sentido, y desde el punto de vista pedagógico, habría que ayudar a los estudiantes a optimizar los procesos de lectura implicados en la utilización de textos y materiales diversos por medio del desarrollo de sus habilidades de selección, organización e integración de información. Por otra parte, el tránsito hacia una concepción más epistémica de los procesos de planificación implicaría instruirles en procedimientos orientados no sólo a generar ideas sino también a configurarlas en consonancia con los objetivos retóricos a cubrir en función de las expectativas de los lectores.

\section{Acknowledgements / Agradecimientos}

The research reported in this paper is part of a progamme of research financed by the Spanish Ministerio de Economía y Competitividad (research grant FF12012-35839) and by Fundación Séneca, the research agency of the Autonomous Government of the region of Murcia, Spain (research grant 11942/PHCS(09) / Esta investigación es parte de un proyecto de investigación financiado por el Ministerio de Economía y Competitividad (FF12012-35839) y por la Fundación Séneca de la Comunidad Autónoma de la Región de Murcia (11942/PHCS(09)). 


\section{Disclosure statement}

No potential conflict of interest was reported by the authors. / Los autores no han referido ningún potencial conflicto de interés en relación con este artículo.

\section{References / Referencias}

Alamargot, D., \& Chanquoy, L. (2001). Through the models of writing. Dordrecht: Kluwer Academic Publishers.

Bereiter, C., \& Scardamalia, M. (1987). The psychology of written composition. Hillsdale, NJ: Lawrence Erlbaum Associates.

Camps, A., \& Castelló, M. (Coords.) (2013). Monográfico: Escritura académica// Academic Writing. REDU. Revista de Docencia Universitaria, 11 (1). Retrieved from http://www.red-u.net/redu/index.php/REDU/issue/view/70

Carey, L., Flower, L., Hayes, J. R., Schriver, K. A., \& Haas, C. (1989). Differences in writers' initial task representations. Retrieved February 22, 2014, from website of National Writing Project: http://www.nwp.org/cs/public/print/nwpr/621

Castelló, M. (2007). El proceso de composición de textos académicos. In M. Castello, A. Iñesta, M. Miras, I. Sole, A. Teberosky, \& M. Zannoto (Eds.), Escribir y Comunicarse en contextos cientificos y academicos. Conocimientos y estrategias (pp. 47-82). Barcelona: Graó.

Castelló, M., Bañales Faz, G., \& Vega López, N. A. (2010). Enfoques en la investigación de la regulación de escritura académica: Estado de la cuestión Electronic Journal of Research in Educational Psychology (online). Retrieved from http://www.redalyc.org/ articulo.oa? id=293122000015

Castelló, M., \& Mateos, M. (2015). Las representaciones de profesores y estudiantes sobre la escritura académica en las universidades españolas. Cultura y Educación, 27, 477503.

Chitez, M., Kruse, O., \& Castelló, M. (in press). The European Writing Survey (EUWRIT): Background, structure, implementation, and some results (Working Papers in Applied Linguistics)., Hochschul-online-Publikationen ZHAW.

Corcelles, M., Oliva, A., Castelló, M., \& Milian, M. (2015). Escribiendo en la Universidad: ¿nos entendemos? Cultura y Educación, 27, 534-568.

Deane, P., Odendahl, N., Quinlan, T., Fowles, M., Welsg, C., \& Bivens-Tatum, J. (2008). Cognitive models of writing: Writing proficiency as a complex integrated skill (Report No. ETS RR-08-55). Princeton, NJ. Educational Testing Service.

Englert, C. S., Mariage, T., \& Dunsmore, T. (2006). Tenets of sociocultural theory in writing instruction research. In A. MacArthur, S. Graham, \& J. Fitzgerald (Eds.), Handbook of writing research (pp. 208-221). New York, NY: Guilford.

Fayol, M., Alamargot, D., \& Berninger, V. (2012). Introduction to the book: From cave writers to elite scribes to professional writers to universal writers, translation is fundamental to writing. In M. Fayol, D. Alamargot, \& V. Berninger (Eds.), Translation of thought to written text while composing (pp. 3-14). New York, NY: Taylor \& Francis Group.

Flower, L. (1994). The construction of negotiated meaning: A social cognitive theory of writing. Carbondale, IL: Southern Illinois University Press.

Flower, L., \& Hayes, J. (1980). The cognition of discovery: Defining a rhetorical problem. College Composition and Communication, 31, 21-33. doi:10.2307/356630

Galbraith, D. (1999). Writing as a knowledge-constituting process. In M. Torrance, \& D. Galbraith (Eds.), Knowing What to Write (pp. 139-160). Amsterdam, NL: Amsterdam University Press.

Galbraith, D. (2009). Writing as discovery. British Journal of Educational Psychology Monograph Series II, 6, 1-23. 
Graham, S., \& Harris, K. R. (2000). The Role of Self-Regulation and Transcription Skills in Writing and Writing Development. Educational Psychologist, 35, 3-12. doi:10.1207/S15326985EP3501_2

Hayes, J. (2012). Evidence from language bursts, revision and transcription for translation and its relation to other writing processes. In M. Fayol, D. Alamargot, \& V. Berninger (Eds.), Translation of thought to written text while composing (pp. 15-25). NewYork, NY: Taylor \& Francis Group.

Hayes, J., Flower, L., Schriver, K., Stratman, J., \& Carey, L. (1987). Cognitive processes in revision. In S. Rosenberg (Ed.), Advances in applied in psycholinguistics (Vol. 2, pp. 176-240). New York, NY: Cambridge University Press.

Hyland, K. (2011). Learning to write: Issues in theory, research, and pedagogy. In R. M. Manchón (ed.), Learning to Write and Writing to Learn in an Additional Language (pp. 17-35). Amsterdam: John Benjamins.

Kruse, O. (2013). Perspectives on academic writing in European higher education: Genres, practices and competences. Revista de Docencia Universitaria RED-U, 11, $37-58$.

Kruse, O., \& Chitez, M. (2012). Contrastive genre mapping in academic contexts: An intercultural approach. Journal of Academic Writing, 2, 59-73.

Landau, S., \& Everitt, B. (2004). A handbook of statistical analyses using SPSS (Vol. 1). Boca Raton, FL: Chapman \& Hall/CRC.

Midgette, E., Haria, P., \& MacArthur, C. (2008). The effects of content and audience awareness goals for revision on the persuasive essays of fifth- and eighth-grade students. Reading and Writing: An Interdisciplinary Journal, 21, 131-151. doi:10.1007/s11145-007-9067-9

Ministerio de Educación Cultura y Deporte (MECD). (2012). Datos Básicos del Sistema Universitario Curso Direcciones. Madrid: Ministerio de Educación Cultura y Deporte.

Roussey, J., \& Piolat, A. (2005). La révision du texte: Une activité de contrôle et de réflexion. Psychologie Française, 50, 351-372. doi:10.1016/j.psfr.2005.05.001

Stevens, J. P. (2009). Applied multivariate statistics for the social sciences. New York, NY: Taylor \& Francis.

Torrance, M., \& Galbraith, D. (2006). The processing demands of writing. In C. A. MacArthur, S. Graham, \& J. Fitzgerald (Eds.), Handbook of writing research (pp. 67-80). New York, NY: Guilford.

Zimmerman, B. J., \& Kitsantas, A. (2007). A writer's discipline: The development of a self-regulatory skill. In S. Hidi, \& P. Boscolo (Eds.), Writing and Motivation (pp. 51-69). Amsterdam: Elsevier. 